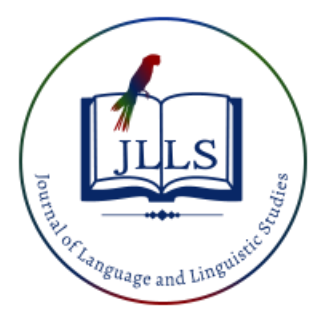

Available online at www.jlls.org

JOURNAL OF LANGUAGE AND LINGUISTIC STUDIES

ISSN: 1305-578X

Journal of Language and Linguistic Studies, 16(4), 1803-1820; 2020

\title{
Gender and socioeconomic status: A pragmatic analysis of politeness strategies used by Iranian EFL students in Persian and English requests
}

\author{
Farzaneh Khakzad Esfahlan $^{\text {a }}$ iD , Mohsen Boroumand ${ }^{\text {b } 1}$ (iD
}

\author{
${ }^{a}$ Allameh Tabatabai University, Tehran, Iran \\ ${ }^{b}$ Istanbul Aydin University, Istanbul, Turkey \\ APA Citation: \\ Khakzad Esfahlan, F., \& Boroumand, M. (2020). Gender and socioeconomic status: A pragmatic analysis of politeness strategies used by \\ Iranian EFL students in Persian and English requests. Journal of Language and Linguistic Studies, 16(4), 1803-1820. \\ Submission Date: 10/07/2020 \\ Acceptance Date: $10 / 09 / 2020$
}

\begin{abstract}
Politeness strategies that speakers deploy when performing a speech act have been seen to be influenced by several factors among which gender and socioeconomic status are two prominent ones. The current study was an attempt to examine the relationship between gender and socioeconomic status (SES) on one hand, and choice of politeness strategies on the other. The focus was specifically on the realization of speech act of request in Persian (L1) and English (L2). The participants were 100 advanced-level Iranian EFL students. Based on their gender and responses to the socioeconomic status questionnaire, they were divided into four equal groups of twenty-five: 1. male-high; 2. male-low; 3. female-high; and 4. female-low. The data collection instruments were the English and Persian versions of a discourse completion test (DCT). The results revealed a significant relationship between gender and use of politeness strategies in speech act of request in L1 as well as L2. The findings, however, demonstrated no significant relationship between the participants' socioeconomic status and their use of politeness strategy neither in L1 nor in L2. This study can be another proof for Brown and Levinson's claim about the universality of politeness strategies.
\end{abstract}

(C) 2020 JLLS and the Authors - Published by JLLS.

Keywords: politeness strategies; gender; socioeconomic status; speech act of request

\section{Introduction}

Within the components of communicative competence, a special emphasis is put on the rules of politeness. Politeness, according to Leech (1983), involves people showing that they think well of others or that they do not think more highly of themselves than they should. This concept has been studied for years, and different scholars have approached it from different perspectives. However, Brown and Levinson's $(1978,1987)$ model of politeness universals still retains its dominance decades after its debut and this makes their model worthy of further consideration.

Brown and Levinson's model is grounded on Goffman's (1967) notion of face - briefly, the public self-image that a person would like to maintain when engaging in social interaction. In their model, Brown and Levinson (1987, p. 62) divide Goffman's notion of face into negative face - "the want of

\footnotetext{
${ }^{1}$ Corresponding author.

E-mail address: mohsenboroumand@aydin.edu.tr
} 
every 'competent adult member' that his actions be unimpeded by others" - and positive face - "the want of every member that his wants be desirable to at least some others". Likewise, if the autonomy or desire of an interlocutor (be it the speaker or the hearer) is challenged, this 'intrusion' is distinguished as face threatening act (FTA).

Requesting is considered by Trosborg (1995) as an instance of FTA in which "a speaker (requester) conveys to a hearer (requestee) that he/she wants the requestee to perform an act which is for the benefit of the speaker" (p. 187). The act of requesting, as he implies, places the speaker at a physical or psychological advantage position over the hearer, and this means that the requester is imposing on the requestee. Brown and Levinson (1987) had speculated this by contending that a speaker, on one hand strives to communicate his want efficiently and urgently, and on the other hand tries to keep the hearer's face untarnished. This assumption is crucial to their theory because it plays a fundamental role in their belief that in order to achieve the 'end' of carrying out face threatening acts, a requester will need to take into account the best possible politeness strategy as 'means'.

There are several factors determining the use of language and accordingly the use of politeness strategies, among which gender and socioeconomic status are two important ones. Women, like people from the lower social classes tend to use more formal and more polite language, while men, as Coates (2015) maintains, like people from the higher social classes tend to use less polite language in different situations, and that might be attributable to their sense of shorter social distance or even their feeling of superiority in the society.

In this regard, a myriad of studies have already been conducted about politeness and politeness strategies on the speakers of English language as well as the speakers of some other languages such as Chinese, Korean, Spanish, and French. Nevertheless, very few empirical studies have examined variables of gender and/or socioeconomic status and their effect on politeness strategy use among Iranian speakers of Persian language and Iranian speakers of English as second language. The body of research becomes even more scant when the use of politeness strategies in the speech act of request is considered.

\subsection{Literature review}

\subsubsection{Politeness strategies}

Brown and Levinson $(1978,1987)$ argue that while communicating, interlocutors always wish to gain respect from their counterparts. Therefore, they need to use appropriate strategies that will best enable them to minimize the threat to their partner's face, to express politeness, and to yield the best communicative effect. Since they proposed the strategies of politeness and suggested the probability of their universality, a large body of theoretical and empirical research including books and articles have been published trying to scrutinize this claim from different angels. These studies have investigated the use of politeness strategies in various cultures and languages. As an example, in a study conducted in the context of Africa, Kariithi (2016) examined the politeness strategies that the Kenyan youth (at secondary school age) employed while communicating with other members of society. The results indicated that the use of politeness strategies was influenced by such factors as the social class of the interlocutors, discourse topic, context, and the reason behind their communication.

In the domain of second/foreign language, various researchers have explored this topic in miscellaneous sociocultural contexts, too. Quraishi (2009), for instance, examined the production of politeness strategies used in letters of inquiry by adult EFL learners in Afghanistan. He found some relationship between proficiency and politeness plus some evidence that the learners' acquisition of linguistic and pragmatic knowledge grow in a parallel fashion. In a similar vein, Senowarsito (2013) explored politeness strategies used in teacher-student classroom interaction, focusing on addressing, thanking, apologizing, and a few more speech acts. The results demonstrated that teachers and students 
tended to use positive, negative, and bald on-record strategies while communicating in English (L2). The researcher concluded that the interlocutors' perception of social distance, age difference, and power as well as their limitations in linguistic ability (L2) had affected the choice of politeness strategies.

It is worth mentioning here that some Iranian researchers, too, have contributed to this issue by investigating the use of politeness strategies in Persian language as L1 and English as L2. Akbari (2002), for example, formulated the range for politeness strategies used by Persian speakers in certain situations, and compared them with their English counterparts in accordance with Brown and Levinson's model. Sahragard (2003), on the other hand, employed cultural script analysis approach to interpret the Persian notion of 'ta' arof' (a type of Persian politeness), and Yarmohammadi (2003) compared and contrasted the use of politeness strategies within the speech acts of favor asking, gripping and complaint across the British English and Persian communities.

In L2 context, Niroomand (2012) examined the ways power relations would affect the choice of politeness strategies by Iranian EFL learners in speech act of disagreement. The Discourse Completion Test (DTC) that was used to elicit the data included five scenarios in which the students were supposed to disagree with two higher statuses, two peers, and one lower status. The results indicated that with regard to the status of the interlocutor, students had used different politeness strategies to soften the FTA of disagreement.

\subsubsection{Speech act of request, gender, and socioeconomic status}

A request, according to Trosborg (1995), is an act which makes the hearer (addressee) do (or do not do) something for the speaker (requester). Accordingly, the act of requesting can benefit the speaker at the cost of the addressee in a physical or psychological fashion, and this, as Brown and Levinson (1978) contend, means that the requester is imposing on the requestee. The intensity of the request determines the intensity of the imposition, and its extent can be governed by such factors as the power (status) differences and familiarity of the hearer and the speaker (i.e. close social distance).

So far, numerous studies in the domains of L1 and L2 have been carried out on the speech act of request that have examined it from different angles. Some have explored request expressions, while some have delved into the effect of gender and/or socioeconomic status on the realization of this speech act.

Harlow (1990), for instance, carried out a study on non-native learners and native speakers of French and inspected the impact of the sex, age, and familiarity among speakers on the realization of the speech acts of requesting, thanking and apologizing. Garcia (1993), likewise, looked at cross-gender differences and similarities between Peruvian Spanish interlocutors when making a request for a service and responding to it. The results revealed some differences between male and female participants which, from a statistical standpoint, were not significant. On the other hand, Macaulay (2001) examined a particular register - interviewing - in which speakers employed questions and/or requests for the purpose of getting information and maintaining conversation. According to the results, the female interviewers, in this study, employed more indirect requests than did the male interviewers. Lorenzo-Dus and BouFranch (2003) also investigated the effect of gender on Spanish and British undergraduates' perception of request. The results of their study showed that both gender groups were disposed towards realizing politeness, yet revealed some differences alongside similarities in their expression of solidarity and deference. And finally, Felix-Brasdefer (2005) examined politeness and indirectness in the speech act of request among Mexican university students in role-play situations. He discovered that in such contexts at least, direct requests are situation-dependent for both male and females and seem to be the expected behavior among these Mexican students in a solidarity politeness system; therefore, directness may not necessarily be counted impolite. 
On the other side of the argument, several studies have investigated the effect of socioeconomic status or social class on the use of request speech act. For instance, Bargiela-Chiappini and Harris (1996) examined the corpora of business correspondence containing requests and identified linguistic variations which they perceived as being ascribable to the influence of such interpersonal variables as social distance, power, and status in particular. Later, Chen and Chen (2007) explored the influence of social status on requesting among Taiwanese EFL learners. The results showed that as far as social status is concerned, when interlocutors are equal, indirect requesting strategy is evidently favored, and when the hearer's social status is superior to that of the speaker's, indirectness strategy for requesting is still preferred but to a lesser extent.

Despite the popularity of this topic among scholars, only few researchers have investigated Iranian culture and Persian language in this respect. Jalilifar (2009), for instance, is among those few who did a cross-sectional analysis on requesting strategies used by Australian native speakers of English and Iranian EFL learners. The result of his study revealed that as in the case of the learners with a higher proficiency, a pragmatic movement from directness to indirectness could be tracked although this led to an overuse of indirect strategies in their requesting; and on the other side of the continuum, the lower proficient learners, were inclined to use direct strategies excessively. This is while the native speakers happened to utilize a relatively balanced proportion of these two types of strategies. In another crosscultural study, conducted to explore the effect of nationality and cultural background on the use of politeness strategies in speech act of request, Rafieyan (2012) compared Iranian and Turkish EFL learners at four different levels of proficiency. Inter- and intra-group analyses showed significant intergroup differences. In other words, the Turkish students used politeness strategies in requestive acts more appropriately than their Iranian counterparts did. More recently, Elmianvari and Kheirabadi (2013) carried out a related research on Iranian EFL students. Students were asked to email their teacher and make a request in an appropriate and polite form. The results showed that most of the students had made their requests in a polite, formal and indirect way through long sentences as an attempt to save the negative face. Eventually, Khandani (2017) probed the perception of speech act of request by Persian native speakers to determine the socially appropriate request patterns in Persian.

Due to the scarcity of related literature on Iranian culture and Persian language, a dire need was felt for studying the relationship between adult Persian speakers' gender and socioeconomic status, as two major variables, and their use of politeness strategy in L1 and L2 while performing the face threatening speech act of request.

\subsection{Purpose of the study}

The first aim of the present study was to determine the relationship between gender and choice of politeness strategies used in the speech act of request. By politeness strategies, we mean the five superstrategies presented by Brown and Levinson (1987) - namely, without redressive action, positive politeness, negative politeness, off record, and withhold the FTA. The second aim was to determine the relationship between socioeconomic status and use of those super-strategies in requests.

\subsection{Research questions}

As a reaction to the aforementioned paucities, the present study intended to answer the following questions:

1. Is there a relationship between the Iranian EFL students' gender and their use of politeness strategies while performing the speech act of request in their first language (i.e. Persian)?

2. Is there a relationship between the Iranian EFL students' gender and their use of politeness 
strategies while performing the speech act of request in their second language (i.e. English)?

3. Is there a relationship between the Iranian EFL students' socioeconomic status and their use of politeness strategies while performing the speech act of request in their first language (i.e. Persian)?

4. Is there a relationship between the Iranian EFL students' socioeconomic status and their use of politeness strategies while performing the speech act of request in their second language (i.e. English)?

\section{Method}

\subsection{Design}

As this research aimed at investigating the relationship between independent variables of gender and socioeconomic status on one hand, and the dependent variable of politeness strategies used in speech act of request on the other, an inter-group analysis design was used. Furthermore, since participants' pragmatic knowledge in their L1 as well as their L2 had already developed and was established prior to this research project, an ex post facto design suited best. The researchers had no control over the selection or manipulation of the independent variables, and the degree of relationship (rather than the causes or effects of the relationship) between the variables of interest were sought.

\subsection{Participants}

The participants in this study were 100 Iranian male and female undergraduate and graduate university students studying English as a foreign language at Islamic Azad University of Dezful. They majored in English language and literature, English translation studies, and English language teaching. Their ages ranged from 19 to 27, and they were at advanced level of proficiency. Six listening ( 2 oncampus talks, 2 student-professor talks, and 2 lectures) and three reading passages of an English proficiency test of TOEFL (Adopted from Phillips, 2015) were used to measure the proficiency level of the participants. The test consisted of 30 reading items and 30 listening items in total. Initially the test was administered to 183 students, and 74 students whose reading scores fell in the band of 24-30 (out of 30) and listening scores in the band of 22-30 (out of 30) were selected. This selection was in accordance with the advanced level band set by Educational Testing Service (ETS) for the TOEFL test. It should also be noted that there were 26 students who already had a valid TOEFL score (i.e. obtained within two years prior to the study) and their reading and listening scores were in the specified bands. They were added to the participants without sitting the mock TOEFL test. Later, on the basis of their gender and answers to the socioeconomic status (SES) questionnaire which assigned a high or low SES for each participant, they were divided into the following four groups: Group 1 (G1): male-high; Group 2 (G2): male-low; Group 3 (G3): female-high; and Group 4 (G4): female-low, each group consisting of 25 students.

\subsection{Instruments}

\subsubsection{Socio-economic status (SES) questionnaire}

A modified SES questionnaire based on 'MacArthur Scale of Subjective Social Status (MacArthur SSS Scale)' developed by Adler, Epel, Castellazzo, and Ickovics (2000) was used to determine the students' socio-economic status. Based on the participants' answers to this questionnaire, they were distributed into two socioeconomic classes: High (upper-middle and high) and low (lower-middle and 
low). Likewise, the participants were asked to specify their gender on the questionnaire form that was necessary to assign them into the four groups of study. In order to elicit as much genuine information as possible, it was explicitly announced that the data was going to be used anonymously only for the purpose of the study and that the information would be treated confidentially.

\subsubsection{Discourse completion test (English and Persian versions)}

A slightly modified version of Marti's (2006) Discourse Completion Test (DCT) was administered to elicit the politeness strategies that participants used in their second language (i.e. English). This test contained 10 situations (scenarios) and for each the students were supposed to write down - in English - what they would have said had they been in such a situation. A Persian translation of the English DCT was also given to elicit the politeness strategies that participants used in their first language. The students answered this test in Persian.

\subsection{Data collection procedures}

The English and Persian versions of the Discourse Completion Test were distributed among the participants during a class period. Each DCT contained 10 situations that invoked request speech act. The students could utilize one or more of the politeness strategies presented by Brown and Levinson (1987) in each situation. As stated earlier, the students were assured that the information would be treated anonymously and confidentially. Besides, the researchers themselves were actively present while the students were filling out the questionnaire, providing further clarification on individual items wherever needed. Then, at the end of the period, both DCTs of each and every participant were picked out and the data were analyzed.

\subsection{Data analysis}

Brown and Levinson's (1987) five politeness super strategies, namely bald on record, positive politeness, negative politeness, off record, and without FTA were used as the framework of this study. The data collected through the L1 and L2 DCTs were categorized under these five super-strategies and Chi-Square analysis was applied on them to see if there was any significant difference in terms of type and frequency of strategies used by males and females in low and high socioeconomic status groups.

\section{Results}

\subsection{Politeness strategies for requesting: Descriptive data}

Table 1 below shows the total frequencies of the utilized strategies in L1 across all ten situations and among the four groups of the study.

Table 1. Frequency of the five super-strategies used by the four groups in their L1

\begin{tabular}{ccccccccccccccccccccc}
\hline \multirow{2}{*}{ L1 } & \multicolumn{3}{c}{ Strategy 1 } & \multicolumn{4}{c}{ Strategy 2 } & \multicolumn{4}{c}{ Strategy 3 } & \multicolumn{4}{c}{ Strategy 4 } & \multicolumn{3}{c}{ Strategy 5 } \\
\cline { 2 - 6 } & G1 & G2 & G3 & G4 & G1 & G2 & G3 & G4 & G1 & G2 & G3 & G4 & G1 & G2 & G3 & G4 & G1 & G2 & G3 & G4 \\
\hline Situation 1 & 12 & 10 & 2 & 3 & 11 & 9 & 24 & 27 & 13 & 19 & 27 & 15 & 0 & 0 & 2 & 1 & 0 & 0 & 1 & 2 \\
\hline Situation 2 & 1 & 2 & 0 & 1 & 6 & 11 & 34 & 38 & 32 & 27 & 30 & 29 & 0 & 0 & 0 & 0 & 0 & 1 & 2 & 0 \\
\hline Situation 3 & 6 & 7 & 1 & 2 & 5 & 3 & 7 & 5 & 29 & 31 & 45 & 47 & 0 & 0 & 0 & 0 & 1 & 0 & 4 & 5 \\
\hline Situation 4 & 14 & 16 & 6 & 3 & 2 & 3 & 8 & 8 & 13 & 11 & 19 & 20 & 0 & 0 & 3 & 3 & 0 & 1 & 0 & 0 \\
\hline Situation 5 & 0 & 0 & 1 & 2 & 14 & 13 & 11 & 17 & 52 & 46 & 48 & 49 & 7 & 7 & 2 & 8 & 1 & 0 & 5 & 3 \\
\hline Situation 6 & 8 & 8 & 3 & 2 & 1 & 2 & 4 & 2 & 19 & 21 & 29 & 27 & 0 & 0 & 3 & 2 & 2 & 2 & 0 & 1 \\
\hline Situation 7 & 4 & 5 & 3 & 1 & 3 & 1 & 6 & 7 & 25 & 28 & 35 & 40 & 1 & 0 & 0 & 0 & 0 & 0 & 0 & 0 \\
\hline
\end{tabular}




\begin{tabular}{ccccccccccccccccccccc}
\hline Situation 8 & 1 & 0 & 0 & 0 & 15 & 16 & 22 & 28 & 41 & 33 & 44 & 47 & 0 & 0 & 0 & 0 & 1 & 1 & 5 & 3 \\
\hline Situation 9 & 0 & 1 & 0 & 0 & 6 & 4 & 11 & 12 & 33 & 34 & 47 & 48 & 0 & 0 & 2 & 3 & 0 & 0 & 6 & 3 \\
\hline Situation 10 & 1 & 2 & 0 & 0 & 21 & 24 & 55 & 54 & 26 & 29 & 34 & 31 & 0 & 0 & 0 & 0 & 0 & 0 & 0 & 0 \\
\hline Total & 47 & 51 & 16 & 14 & 84 & 86 & 182 & 198 & 283 & 279 & 358 & 353 & 8 & 7 & 12 & 17 & 5 & 5 & 23 & 17 \\
\hline
\end{tabular}

By observing the total frequencies, one can see that apart from the first strategy (i.e. bald on record) which was used more by the first (male-high) and the second (male-low) groups, the other strategies were used more by the third (female-high) and the fourth (female-low) groups. Regarding the total frequencies, the table shows that the frequency of strategies used by group 1 (male-high) is so close to that of group 2 (male-low); likewise, the frequency of strategies used by group 3 (female-high) is so close to that of group 4 (female-low). This is consistent across all strategies.

Table 2 depicts the total frequencies of the five super-strategies across all ten situations used by either gender at low or high SES in their L1.

Table 2. Frequency of the five super-strategies used by males $(\mathrm{M})$, females $(\mathrm{F})$, high $(\mathrm{H})$ and low $(\mathrm{L})$ SES in L1

\begin{tabular}{|c|c|c|c|c|c|c|c|c|c|c|c|c|c|c|c|c|c|c|c|c|}
\hline \multirow[b]{2}{*}{ L1 } & \multicolumn{4}{|c|}{ Strategy 1} & \multicolumn{4}{|c|}{ Strategy 2} & \multicolumn{4}{|c|}{ Strategy 3} & \multicolumn{4}{|c|}{ Strategy 4} & \multicolumn{4}{|c|}{ Strategy 5} \\
\hline & M & $\mathrm{F}$ & $\mathrm{H}$ & $\mathrm{L}$ & M & F & $\mathrm{H}$ & $\mathrm{L}$ & M & $\mathrm{F}$ & $\mathrm{H}$ & $\mathrm{L}$ & M & $\mathrm{F}$ & $\mathrm{H}$ & $\mathrm{L}$ & M & F & $\mathrm{H}$ & $\mathrm{L}$ \\
\hline Situation 1 & 22 & 5 & 14 & 13 & 20 & 51 & 35 & 36 & 32 & 42 & 40 & 34 & 0 & 3 & 2 & 1 & 0 & 3 & 1 & 2 \\
\hline Situation 2 & 3 & 1 & 1 & 3 & 17 & 72 & 40 & 49 & 59 & 59 & 62 & 56 & 0 & 0 & 0 & 0 & 1 & 2 & 2 & 1 \\
\hline Situation 3 & 13 & 3 & 7 & 9 & 8 & 12 & 12 & 8 & 60 & 92 & 74 & 78 & 0 & 0 & 0 & 0 & 1 & 9 & 5 & 5 \\
\hline Situation 4 & 30 & 9 & 20 & 19 & 5 & 16 & 10 & 11 & 24 & 39 & 32 & 31 & 0 & 6 & 3 & 3 & 1 & 0 & 0 & 1 \\
\hline Situation 5 & 0 & 3 & 1 & 2 & 27 & 28 & 25 & 30 & 98 & 97 & 100 & 95 & 14 & 10 & 9 & 15 & 1 & 8 & 6 & 3 \\
\hline Situation 6 & 16 & 5 & 11 & 10 & 3 & 6 & 5 & 4 & 40 & 56 & 48 & 48 & 0 & 5 & 3 & 2 & 4 & 1 & 2 & 3 \\
\hline Situation 7 & 9 & 4 & 7 & 6 & 4 & 13 & 9 & 8 & 53 & 75 & 60 & 68 & 1 & 0 & 1 & 0 & 0 & 0 & 0 & 0 \\
\hline Situation 8 & 1 & 0 & 1 & 0 & 31 & 50 & 37 & 44 & 74 & 91 & 85 & 80 & 0 & 0 & 0 & 0 & 2 & 8 & 6 & 4 \\
\hline Situation 9 & 1 & 0 & 0 & 1 & 10 & 23 & 17 & 16 & 67 & 95 & 80 & 82 & 0 & 5 & 2 & 3 & 0 & 9 & 6 & 3 \\
\hline Situation10 & 3 & 0 & 1 & 2 & 45 & 109 & 76 & 78 & 55 & 65 & 60 & 60 & 0 & 0 & 0 & 0 & 0 & 0 & 0 & 0 \\
\hline Total & 98 & 30 & 63 & 65 & 170 & 380 & 266 & 284 & 562 & 711 & 641 & 632 & 15 & 29 & 20 & 24 & 10 & 40 & 28 & 22 \\
\hline
\end{tabular}

Regarding Table 2, it can be discerned that all strategies were used more by females than by males except for strategy 1 (i.e. bald on record). It seems, according to these frequencies, that males tend to be more direct while females tend to use more indirect strategies when making a request in their L1. Besides, little differences were observed between the frequencies of strategies used by high and low socioeconomic status (SES) participants.

Table 3 illustrates the frequency of the five super-strategies used by the four groups in their second language (English).

Table 3. Frequency of the five super-strategies used by the four groups in their L2

\begin{tabular}{lcccccccccccccccccccc}
\hline \multirow{2}{*}{ L2 } & \multicolumn{3}{c}{ Strategy 1 } & \multicolumn{4}{c}{ Strategy 2 } & \multicolumn{4}{c}{ Strategy 3 } & \multicolumn{4}{c}{ Strategy 4 } & \multicolumn{3}{c}{ Strategy 5 } \\
\cline { 2 - 6 } & G1 & G2 & G3 & G4 & G1 & G2 & G3 & G4 & G1 & G2 & G3 & G4 & G1 & G2 & G3 & G4 & G1 & G2 & G3 & G4 \\
\hline Situation 1 & 10 & 8 & 5 & 7 & 6 & 6 & 8 & 6 & 14 & 18 & 19 & 15 & 0 & 0 & 1 & 0 & 0 & 0 & 1 & 2 \\
\hline Situation 2 & 7 & 8 & 2 & 3 & 4 & 8 & 20 & 25 & 19 & 15 & 29 & 26 & 0 & 0 & 1 & 1 & 2 & 1 & 2 & 0 \\
\hline Situation 3 & 9 & 9 & 1 & 1 & 5 & 5 & 10 & 12 & 17 & 17 & 33 & 31 & 0 & 1 & 0 & 0 & 1 & 1 & 4 & 5 \\
\hline Situation 4 & 15 & 15 & 7 & 7 & 2 & 4 & 7 & 7 & 9 & 8 & 17 & 18 & 0 & 0 & 3 & 1 & 0 & 0 & 0 & 0 \\
\hline Situation 5 & 0 & 0 & 0 & 0 & 12 & 10 & 15 & 15 & 31 & 31 & 34 & 40 & 2 & 4 & 3 & 3 & 1 & 0 & 5 & 3 \\
\hline Situation 6 & 10 & 10 & 4 & 1 & 4 & 5 & 10 & 10 & 14 & 16 & 16 & 22 & 2 & 2 & 0 & 0 & 1 & 1 & 0 & 1 \\
\hline Situation 7 & 10 & 7 & 2 & 2 & 5 & 6 & 12 & 7 & 16 & 18 & 28 & 29 & 0 & 1 & 0 & 0 & 0 & 1 & 0 & 0 \\
\hline Situation 8 & 1 & 1 & 0 & 0 & 11 & 10 & 15 & 20 & 19 & 24 & 28 & 39 & 1 & 2 & 0 & 0 & 1 & 0 & 5 & 3 \\
\hline
\end{tabular}




\begin{tabular}{ccccccccccccccccccccc}
\hline Situation 9 & 6 & 7 & 2 & 1 & 9 & 8 & 12 & 15 & 13 & 15 & 29 & 36 & 1 & 0 & 0 & 0 & 1 & 2 & 6 & 3 \\
\hline Situation 10 & 6 & 7 & 1 & 2 & 13 & 12 & 41 & 41 & 12 & 15 & 28 & 25 & 0 & 0 & 0 & 0 & 0 & 0 & 0 & 0 \\
\hline Total & 74 & 72 & 24 & 24 & 71 & 74 & 150 & 158 & 164 & 177 & 261 & 281 & 6 & 10 & 8 & 5 & 7 & 6 & 23 & 17 \\
\hline
\end{tabular}

A comparison between Table 3 and Table 1 shows that the ratio of total frequencies in L1 and L2 are similar. That is, in both L1 and L2, the first strategy was used more by group 1 (male-high) and group 2 (male-low), but the other strategies were used more by group 3 (female-high) and group 4 (femalelow), except strategy 4 (i.e. off-record) which was used more by male-low participants in their L2. By analyzing the total frequencies, it can be observed that the frequency of the strategies used by group 1 (male-high) is so close to the frequency of the strategies used by group 2 (male-low); in addition, the frequency of the strategies used by group 3 (female-high) is so close to that of group 4 (female-low). This congruency exists in all strategies used by either gender.

Finally, Table 4 depicts the total frequencies of the five super-strategies across all ten situations used by either gender at low or high SES in their L2 (English).

Table 4. Frequency of the five super-strategies used by males (M), females (F), high (H) and low (L) SES in L2

\begin{tabular}{cccccccccccccccccccccc}
\hline & \multicolumn{3}{c}{ Strategy 1 } & \multicolumn{1}{c}{ Strategy 2 } & \multicolumn{1}{c}{ Strategy 3 } & \multicolumn{4}{c}{ Strategy 4 } & \multicolumn{3}{c}{ Strategy 5 } \\
\cline { 2 - 6 } & L & F & H & L & M & F & H & L & M & F & H & L & M & F & H & L & M & F & H & L \\
\hline Situation 1 & 18 & 12 & 15 & 15 & 12 & 14 & 14 & 12 & 32 & 34 & 33 & 33 & 0 & 1 & 1 & 0 & 0 & 3 & 1 & 2 \\
\hline Situation 2 & 15 & 5 & 9 & 11 & 12 & 45 & 24 & 33 & 34 & 55 & 48 & 41 & 0 & 2 & 1 & 1 & 3 & 2 & 4 & 1 \\
\hline Situation 3 & 18 & 2 & 10 & 10 & 10 & 22 & 15 & 17 & 34 & 64 & 50 & 48 & 1 & 0 & 0 & 1 & 2 & 9 & 5 & 6 \\
\hline Situation 4 & 30 & 14 & 22 & 22 & 6 & 14 & 9 & 11 & 17 & 35 & 26 & 26 & 0 & 4 & 3 & 1 & 0 & 0 & 0 & 0 \\
\hline Situation 5 & 0 & 0 & 0 & 0 & 22 & 30 & 27 & 25 & 62 & 74 & 65 & 71 & 6 & 6 & 5 & 7 & 1 & 8 & 6 & 3 \\
\hline Situation 6 & 20 & 5 & 14 & 11 & 9 & 20 & 14 & 15 & 30 & 38 & 30 & 38 & 4 & 0 & 2 & 2 & 2 & 1 & 1 & 2 \\
\hline Situation 7 & 17 & 4 & 12 & 9 & 11 & 19 & 17 & 13 & 34 & 57 & 44 & 47 & 1 & 0 & 0 & 1 & 1 & 0 & 0 & 1 \\
\hline Situation 8 & 2 & 0 & 1 & 1 & 21 & 35 & 26 & 30 & 43 & 67 & 47 & 63 & 3 & 0 & 1 & 2 & 1 & 8 & 6 & 3 \\
\hline Situation 9 & 13 & 3 & 8 & 8 & 17 & 27 & 21 & 23 & 28 & 65 & 42 & 51 & 1 & 0 & 1 & 0 & 3 & 9 & 7 & 5 \\
\hline Situation 10 & 13 & 3 & 7 & 9 & 25 & 82 & 54 & 53 & 27 & 53 & 40 & 40 & 0 & 0 & 0 & 0 & 0 & 0 & 0 & 0 \\
\hline Total & 146 & 48 & 98 & 96 & 145 & 308 & 221 & 232 & 341 & 542 & 425 & 458 & 16 & 13 & 14 & 15 & 13 & 40 & 30 & 23 \\
\hline
\end{tabular}

By examining the total frequencies of the strategies used in L2 (Table 4), it can be perceived that all strategies were used more by females than by males except for strategy 1 (bald on record) and strategy 4 (off-record) although this difference is so little for the fourth strategy. This observation may lead us to think that males prefer to be more direct when presenting a request in their L2 while females tend to be more indirect. Moreover, with regard to the collected data in Table 4, little difference is detectable between the frequency of strategies used by high and low SES participants. These results are similar to the results of strategy use in the participants' L1 except strategy 4.

\subsection{Analysis of gender and politeness strategy use in speech act of request (L1)}

Since only nominal variables were included and frequencies were compared, Chi-square analysis was the most appropriate test to be used. Moreover, it is worth mentioning here that because the degree of freedom equaled one in all of the calculations, Yate's correction factor was applied in the computations. To begin with, one-way Chi-square analysis was applied on the frequencies of the five politeness strategies used by males and females in their first language (L1) to determine whether the observed differences were significant $(\rho<0.05)$. The following statistics were obtained: 
Table 5. One-way Chi-square: The relationship between gender and politeness strategy use in L1

\begin{tabular}{|c|c|c|c|c|c|c|c|c|}
\hline \multirow[b]{2}{*}{$\begin{array}{l}\text { Strategy } \\
\text { L1 }\end{array}$} & \multicolumn{2}{|c|}{ Gender } & \multirow[b]{2}{*}{$\begin{array}{l}\text { Expected } \\
\text { Frequency }\end{array}$} & \multirow[b]{2}{*}{$\begin{array}{l}\text { Total } \\
\text { (freq.) }\end{array}$} & \multirow[b]{2}{*}{$\begin{array}{c}\text { Chi Square } \\
\left(x^{2}\right)\end{array}$} & \multirow[b]{2}{*}{$\rho$-value } & \multirow[b]{2}{*}{$\operatorname{Phi}(\varphi)$} & \multirow[b]{2}{*}{$d f$} \\
\hline & $\begin{array}{c}\text { Male } \\
\text { (observed freq.) }\end{array}$ & $\begin{array}{c}\text { Female } \\
\text { (observed freq.) }\end{array}$ & & & & & & \\
\hline 1 & 98 & 30 & 64 & 128 & 35.08 & 0.0001 & 0.52 & 1 \\
\hline 2 & 170 & 380 & 275 & 550 & 79.42 & 0.0001 & 0.38 & 1 \\
\hline 3 & 562 & 711 & 636.5 & 1273 & 17.2 & 0.0001 & 0.11 & 1 \\
\hline 4 & 15 & 29 & 22 & 44 & 3.840 & 0.05 & $\begin{array}{ll}--- \\
--\end{array}$ & 1 \\
\hline 5 & 10 & 40 & 25 & 50 & 16.82 & 0.0001 & 0.58 & 1 \\
\hline
\end{tabular}

As Table 5 displays, the Chi-square values for strategies 1,2, 3 and 5 at 1 degree of freedom were $35.08,79.42,17.2$ and 16.82 in sequence which were all greater than the critical value of $x^{2}(3.841)$ at the .05 level of probability. Moreover, as the table shows, the $\mathrm{x}^{2}$ values were significant at $\rho=0.0001$ level for strategies $1,2,3$, and 5. This indicates that there was a statistically significant relationship between the participants' gender and their use of these strategies in L1. Nevertheless, the $\mathrm{x}^{2}$ value for strategy 4 at 1 degree of freedom was 3.840, which is smaller than the critical value of $x^{2}(3.841)$ at the .05 level of probability. Therefore, the $\mathrm{x}^{2}$ value was not significant for this strategy in L1.

Additionally, to estimate the strength of relationship between the two variables of interest (i.e. gender and use of politeness strategies), Phi $(\varphi)$ values were also calculated for every pair of variables except the fourth pair which did not have a significant $\mathrm{x}^{2}$ value. Based on the results shown in Table 5, it can be seen that all paired variables that had a significant $x^{2}$ value share a significant overlap $(\varphi=0.52$ for gender and strategy $1, \varphi=0.38$ for gender and strategy $2, \varphi=0.11$ for gender and strategy 3 , and $\varphi=$ 0.58 for gender and strategy 5 ). As a result, there was a fairly strong relationship between the variables of interest, except for the fourth pair.

Next, in order to investigate the relationship between gender and politeness strategy use in the participants' L1 with regard to their socioeconomic status, Chi-square analysis was applied to the frequencies of politeness strategies used by group 1 (male-high) and group 3 (female-high) participants in their first language (L1). Table 6 presents the results of this analysis.

Table 6. One-way Chi-square: Inter-group relationship between male-high and female-high in terms of politeness strategy use in L1

\begin{tabular}{|c|c|c|c|c|c|c|c|c|}
\hline \multirow[b]{2}{*}{$\begin{array}{l}\text { Strategy } \\
\text { L1 }\end{array}$} & \multicolumn{2}{|c|}{ Gender + Socio-economic Status } & \multirow[b]{2}{*}{$\begin{array}{l}\text { Expected } \\
\text { Frequency }\end{array}$} & \multirow[b]{2}{*}{$\begin{array}{l}\text { Total } \\
\text { (freq.) }\end{array}$} & \multirow[b]{2}{*}{$\begin{array}{c}\text { Chi Square } \\
\left(x^{2}\right)\end{array}$} & \multirow[b]{2}{*}{$\rho$-value } & \multirow[b]{2}{*}{$P h i(\varphi)$} & \multirow[b]{2}{*}{$d f$} \\
\hline & $\begin{array}{c}\text { Male-High } \\
\text { (observed freq.) }\end{array}$ & $\begin{array}{l}\text { Female-High } \\
\text { (observed freq.) }\end{array}$ & & & & & & \\
\hline 1 & 47 & 16 & 31.5 & 63 & 14.28 & 0.0002 & 0.47 & 1 \\
\hline 2 & 84 & 182 & 133 & 266 & 35.38 & 0.0001 & 0.36 & 1 \\
\hline 3 & 283 & 358 & 320.5 & 641 & 8.54 & 0.0035 & 0.11 & 1 \\
\hline 4 & 8 & 12 & 10 & 20 & 0.46 & 0.49 & ---- & 1 \\
\hline 5 & 5 & 23 & 14 & 28 & 10.32 & 0.0013 & 0.60 & 1 \\
\hline
\end{tabular}

According to Table 6, the Chi-square values for strategies 1,2,3, and 5 at 1 degree of freedom were in sequence $14.28,35.38,8.54$, and 10.32, which were all larger than the critical value of $x^{2}(3.841)$ at the 0.05 level of probability. Moreover, with regard to the table, the $x^{2}$ values were significant at $\rho=$ 0.0002 level for strategy $1, \rho=0.0001$ for strategy $2, \rho=0.0035$ for strategy 3 , and at $\rho=0.0013$ level for strategy 5 . These results reveal that there was a statistically significant relationship between the variables of gender and politeness strategy use in L1 for high SES participants. Besides, the estimate of the Phi $(\varphi)$ values for each pair $(\varphi=0.47$ for gender and strategy $1, \varphi=0.36$ for gender and strategy 2 , $\varphi=0.11$ for gender and strategy 3 , and $\varphi=0.60$ for gender and strategy 5 ) shows that the above 
mentioned relationship is pretty strong except for the use of strategy 4 which has an insignificant Chisquare value.

Subsequently, the same analysis was applied to the frequencies of politeness strategy use in L1 between group 2 (male-low) and group 4 (female-low). The results of this analysis are presented in Table 7.

Table 7. One-way Chi-square: Inter-group relationship between male-low and female-low in terms of politeness strategy use in L1

\begin{tabular}{|c|c|c|c|c|c|c|c|c|}
\hline \multirow[b]{2}{*}{$\begin{array}{l}\text { Strategy } \\
\text { L1 }\end{array}$} & \multicolumn{2}{|c|}{ Gender + Socio-economic Status } & \multirow[b]{2}{*}{$\begin{array}{l}\text { Expected } \\
\text { Frequency }\end{array}$} & \multirow[b]{2}{*}{$\begin{array}{l}\text { Total } \\
\text { (freq.) }\end{array}$} & \multirow[b]{2}{*}{$\begin{array}{c}\text { Chi Square } \\
\left(x^{2}\right)\end{array}$} & \multirow[b]{2}{*}{$\rho$-value } & \multirow[b]{2}{*}{$\operatorname{Phi}(\varphi)$} & \multirow[b]{2}{*}{$d f$} \\
\hline & $\begin{array}{c}\text { Male-Low } \\
\text { (observed freq.) }\end{array}$ & $\begin{array}{c}\text { Female-Low } \\
\text { (observed freq.) }\end{array}$ & & & & & & \\
\hline 1 & 51 & 14 & 32.5 & 65 & 19.94 & 0.0001 & 0.55 & 1 \\
\hline 2 & 86 & 198 & 142 & 284 & 43.38 & 0.0001 & 0.39 & 1 \\
\hline 3 & 279 & 353 & 316 & 632 & 8.44 & 0.0037 & 0.11 & 1 \\
\hline 4 & 7 & 17 & 12 & 24 & 3.38 & 0.066 & ---- & 1 \\
\hline 5 & 5 & 17 & 11 & 22 & 5.50 & 0.019 & 0.50 & 1 \\
\hline
\end{tabular}

As Table 7 shows, the Chi-square values for strategies 1,2, 3, and 5 at 1 degree of freedom were $19.94,43.38,8.44$, and 5.50 respectively, which were all greater than the critical value of $x^{2}(3.841)$ at the .05 level of probability. In addition, the $x^{2}$ values were significant at $\rho=0.0001$ level for strategies 1 and $2, \rho=0.0037$ for strategy 3 , and at $\rho=0.019$ level for strategy 5 . These results generally point out that the relationship between the low SES participants' gender and their use of politeness strategies in L1 was statistically significant. Also, the calculated Phi $(\varphi)$ values for each pair of variables $(\varphi=0.55$ for gender and strategy $1, \varphi=0.39$ for gender and strategy $2, \varphi=0.11$ for gender and strategy 3 , and $\varphi$ $=0.50$ for gender and strategy 5 ) show that the relationship between these variables is quite strong; however, the use of the fourth strategy is an exception again, and the obtained $\mathrm{x}^{2}$ value is not considerable.

\subsection{Analysis of gender and politeness strategy use in speech act of request (L2)}

To investigate the relationship between the participants' gender and their use of politeness strategies in L2, again Chi-square analysis was applied to the frequencies of the five strategies used by males and females in their second language (English). The results of this analysis are displayed in Table 8.

Table 8. One-way Chi-square: The relationship between gender and politeness strategy use in L2

\begin{tabular}{ccccccccc}
\hline \multirow{2}{*}{$\begin{array}{c}\text { Strategy } \\
\text { L2 }\end{array}$} & $\begin{array}{c}\text { Male } \\
\text { (observed freq.) }\end{array}$ & $\begin{array}{c}\text { Female } \\
\text { (observed freq.) }\end{array}$ & $\begin{array}{c}\text { Expected } \\
\text { Frequency }\end{array}$ & $\begin{array}{c}\text { Total } \\
\text { (freq.) }\end{array}$ & $\begin{array}{c}\text { Chi Square } \\
\left(x^{2}\right)\end{array}$ & $\rho$-value & Phi $(\varphi)$ & $d f$ \\
\hline 1 & 146 & 48 & 97 & 194 & 48.5 & 0.0001 & 0.50 & 1 \\
\hline 2 & 145 & 308 & 226.5 & 453 & 57.94 & 0.0001 & 0.35 & 1 \\
\hline 3 & 341 & 542 & 441.5 & 883 & 45.3 & 0.0001 & 0.22 & 1 \\
\hline 4 & 16 & 13 & 14.5 & 29 & 0.14 & 0.708 & $---1_{n}^{n}$ & 1 \\
\hline 5 & 13 & 40 & 26.5 & 53 & 12.76 & 0.0004 & 0.49 & 1 \\
\hline
\end{tabular}

The Chi-square values for strategies 1, 2, 3, and 5 at 1 degree of freedom were 48.5, 57.94, 45.3, and 12.76 (Table 9) which were all larger than the critical value of $\mathrm{x}^{2}(3.841)$ at .05 level of probability. Furthermore, as the table shows, the $\mathrm{x}^{2}$ values were significant at $\rho=0.0001$ level for strategies 1,2 , and 3, and at $\rho=0.0004$ level for strategy 5 . This indicates that there was a statistically significant relationship between the participants' gender and their use of these strategies in their L2. Meanwhile, the estimate of the Phi $(\varphi)$ values for each pair of variables $(\varphi=0.50$ for gender and strategy $1, \varphi=0.35$ for gender and strategy $2, \varphi=0.22$ for gender and strategy 3 , and $\varphi=0.49$ for gender and strategy 5 ) 
shows that the above mentioned relationship is rather strong. However, the $x^{2}$ value for strategy 4 at 1 degree of freedom was 0.14 which is smaller than the critical value of $\mathrm{x}^{2}(3.841)$ at the 0.05 level of probability. Therefore, the $\mathrm{x}^{2}$ value was not significant for this strategy in L2.

In a similar vein, the results of the Chi-square analysis applied to the frequencies of the five politeness strategies used by group 1 (male-high) and group 3 (female-high) participants in the second language (L2) for strategies 1, 2, 3, and 5 at 1 degree of freedom were 24.50, 27.52, 21.68, and 7.50 sequentially (Table 9). These were all greater than the critical value of $x^{2}$ (3.841) at the .05 level of probability. Also, the $\mathrm{x}^{2}$ values were significant at $\rho=0.0001$ level for strategies $1,2,3$, and at $\rho=0.006$ level for strategy 5. Overall, these findings confirm a statistically significant relationship between the high SES participants' gender and their use of politeness strategies in L2. Besides, the Phi $(\varphi)$ values for each pair $(\varphi=0.5$ for gender and strategy $1, \varphi=0.35$ for gender and strategy $2, \varphi=0.22$ for gender and strategy 3 , and $\varphi=0.5$ for gender and strategy 5 ) demonstrate a strong relationship between the variables, with strategy 4 an exception that does not have a significant Chi-square value.

Table 9. One-way Chi-square: Inter-group relationship between male-high and female-high in terms of politeness strategy use in L2

\begin{tabular}{|c|c|c|c|c|c|c|c|c|}
\hline \multirow{2}{*}{$\begin{array}{l}\text { Strategy } \\
\text { L2 }\end{array}$} & \multicolumn{2}{|c|}{ Gender + Socio-economic Status } & \multirow[b]{2}{*}{$\begin{array}{l}\text { Expected } \\
\text { Frequency }\end{array}$} & \multirow[b]{2}{*}{$\begin{array}{l}\text { Total } \\
\text { (freq.) }\end{array}$} & \multirow{2}{*}{$\begin{array}{l}\text { Chi Square } \\
\qquad\left(x^{2}\right)\end{array}$} & \multirow[b]{2}{*}{$\rho$-value } & \multirow[b]{2}{*}{$\operatorname{Phi}(\varphi)$} & \multirow[b]{2}{*}{$d f$} \\
\hline & $\begin{array}{c}\text { Male-High } \\
\text { (observed freq.) }\end{array}$ & $\begin{array}{c}\text { Female-High } \\
\text { (observed freq.) }\end{array}$ & & & & & & \\
\hline 1 & 74 & 24 & 49 & 98 & 24.50 & 0.0001 & 0.5 & 1 \\
\hline 2 & 71 & 150 & 110.5 & 221 & 27.52 & 0.0001 & 0.35 & 1 \\
\hline 3 & 164 & 261 & 212.5 & 425 & 21.68 & 0.0001 & 0.22 & 1 \\
\hline 4 & 6 & 8 & 7 & 14 & 0.08 & 0.77 & --- & 1 \\
\hline 5 & 7 & 23 & 15 & 30 & 7.50 & 0.006 & 0.5 & 1 \\
\hline
\end{tabular}

The calculations were continued by performing Chi-square analysis on the frequencies of the five politeness strategies used by group 2 (male-low) and group 4 (female-low) participants in their second language (Table 10). For strategies 1, 2, 3, and 5 at 1 degree of freedom the results were 23.02, 29.70, 23.16, and 4.34 in sequence, which were all greater than the critical value of $x^{2}(3.841)$ at the .05 level of probability. Moreover, the significance level of the obtained Chi-squares were $\rho=00001$ for strategies 1,2 , and 3 , and $\rho=0.037$ for strategy 5 . Hence, it can be concluded that there was a statistically significant relationship between the low SES participants' gender and their use of politeness strategies in English. The estimate of the Phi $(\varphi)$ values for each pair of variables $(\varphi=0.48$ for gender and strategy $1, \varphi=0.35$ for gender and strategy $2, \varphi=0.22$ for gender and strategy 3 , and $\varphi=0.43$ for gender and strategy 5) proved a vigorous relationship, excluding strategy 4 as an exception that had an insignificant relationship with the variable of gender.

Table 10. One-way Chi-square: Inter-group relationship between male-low and female-low in terms of strategy use in L2

\begin{tabular}{|c|c|c|c|c|c|c|c|c|}
\hline \multirow[b]{2}{*}{$\begin{array}{l}\text { Strategy } \\
\text { L2 }\end{array}$} & \multicolumn{2}{|c|}{ Gender + Socio-economic Status } & \multirow[b]{2}{*}{$\begin{array}{l}\text { Expected } \\
\text { Frequency }\end{array}$} & \multirow[b]{2}{*}{$\begin{array}{l}\text { Total } \\
\text { (freq.) }\end{array}$} & \multirow[b]{2}{*}{$\begin{array}{c}\text { Chi Square } \\
\left(x^{2}\right)\end{array}$} & \multirow[b]{2}{*}{$\rho$-value } & \multirow[b]{2}{*}{$\operatorname{Phi}(\varphi)$} & \multirow[b]{2}{*}{$d f$} \\
\hline & $\begin{array}{c}\text { Male-Low } \\
\text { (observed freq.) }\end{array}$ & $\begin{array}{c}\text { Female-Low } \\
\text { (observed freq.) }\end{array}$ & & & & & & \\
\hline 1 & 72 & 24 & 48 & 96 & 23.02 & 0.0001 & 0.48 & 1 \\
\hline 2 & 74 & 158 & 116 & 232 & 29.70 & 0.0001 & 0.35 & 1 \\
\hline 3 & 177 & 281 & 229 & 458 & 23.16 & 0.0001 & 0.22 & 1 \\
\hline 4 & 10 & 5 & 7.5 & 15 & 1.06 & 0.30 & --- & 1 \\
\hline 5 & 6 & 17 & 11.5 & 23 & 4.34 & 0.037 & 0.43 & 1 \\
\hline
\end{tabular}




\subsection{Analysis of socioeconomic status and politeness strategy use in speech act of request (L1)}

The researchers executed Chi-square analysis one more time to the frequencies of the five politeness strategies used by high and low SES participants to see if there was a relationship between the socioeconomic status and the use of politeness strategies in L1. Table11 displays the results of this analysis. The calculated statistics available in this table present the Chi-square values for strategies 1, 2, 3,4 , and 5 at 1 degree of freedom which were in order 0.0, 0.52, 0.06, 0.20, and 0.50. All of them were smaller than the critical value of $x^{2}$ (3.841) at the .05 level of probability. Therefore, it could be concluded that there was not a statistically significant relationship between the participants' socioeconomic status and their use of politeness super-strategies in Persian while making requests.

Table 11. One-way Chi-square: The relationship between SES and politeness strategy use in L1

\begin{tabular}{|c|c|c|c|c|c|c|c|c|}
\hline \multirow[b]{2}{*}{$\begin{array}{l}\text { Strategy } \\
\text { L1 }\end{array}$} & \multicolumn{2}{|c|}{ Socio-economic Status } & \multirow[b]{2}{*}{$\begin{array}{l}\text { Expected } \\
\text { Frequency }\end{array}$} & \multirow[b]{2}{*}{$\begin{array}{c}\text { Total } \\
\text { (freq.) }\end{array}$} & \multirow[b]{2}{*}{$\begin{array}{l}\text { Chi Square } \\
\left(x^{2}\right)\end{array}$} & \multirow[b]{2}{*}{$\rho$-value } & \multirow[b]{2}{*}{$P h i(\varphi)$} & \multirow[b]{2}{*}{$d f$} \\
\hline & $\begin{array}{c}\text { High } \\
\text { (observed freq.) }\end{array}$ & $\begin{array}{c}\text { Low } \\
\text { (observed freq.) }\end{array}$ & & & & & & \\
\hline 1 & 63 & 65 & 64 & 128 & 0 & 1 & ---- & 1 \\
\hline 2 & 266 & 284 & 275 & 550 & 0.52 & 0.47 & ---- & 1 \\
\hline 3 & 641 & 632 & 636.5 & 1273 & 0.06 & 0.80 & ---- & 1 \\
\hline 4 & 20 & 24 & 22 & 44 & 0.20 & 0.65 & ---- & 1 \\
\hline 5 & 28 & 22 & 25 & 50 & 0.50 & 0.47 & ---- & 1 \\
\hline
\end{tabular}

Thereafter, in order to explore the relationship between the participants' SES and their use of politeness strategies in Persian with regard to their gender, Chi-square analysis was firstly applied to the frequencies of the five politeness strategies used by group 1 (male-high) and group 2 (male-low) participants in their L1. Table12 presents the results. It can be observed that the Chi-square values for strategies $1,2,3,4$, and 5 at 1 degree of freedom were consecutively $0.10,0.0,0.02,0.0$, and 0.0 . They were all smaller than the critical value of $\mathrm{x}^{2}(3.841)$ at the .05 level of probability. Therefore, as the table shows, the $\mathrm{x}^{2}$ values are not significant for strategies 1,2,3,4 and 5. Accordingly, from a statistical perspective, there is not a significant relationship between male participants' SES and their use of the politeness strategies in Persian.

Table 12. One-way Chi-square: Intergroup relationship between male-high and male-low in terms of politeness strategy use in L1

\begin{tabular}{|c|c|c|c|c|c|c|c|c|}
\hline \multirow{2}{*}{$\begin{array}{l}\text { Strategy } \\
\text { L1 }\end{array}$} & \multicolumn{2}{|c|}{ Gender + Socio-economic Status } & \multirow[b]{2}{*}{$\begin{array}{l}\text { Expected } \\
\text { Frequency }\end{array}$} & \multirow[b]{2}{*}{$\begin{array}{l}\text { Total } \\
\text { (freq.) }\end{array}$} & \multirow[b]{2}{*}{$\begin{array}{c}\text { Chi Square } \\
\left(x^{2}\right)\end{array}$} & \multirow[b]{2}{*}{$\rho$-value } & \multirow[b]{2}{*}{$\operatorname{Phi}(\varphi)$} & \multirow[b]{2}{*}{$d f$} \\
\hline & $\begin{array}{c}\text { Male-High } \\
\text { (observed freq.) }\end{array}$ & $\begin{array}{c}\text { Male-Low } \\
\text { (observed freq.) }\end{array}$ & & & & & & \\
\hline 1 & 47 & 51 & 49 & 98 & 0.10 & 0.75 & ---- & 1 \\
\hline 2 & 84 & 86 & 85 & 170 & 0 & 1 & --- & 1 \\
\hline 3 & 283 & 279 & 281 & 562 & 0.02 & 0.88 & ---- & 1 \\
\hline 4 & 8 & 7 & 7.5 & 15 & 0 & 1 & --- & 1 \\
\hline 5 & 5 & 5 & 5 & 10 & 0 & 1 & ---- & 1 \\
\hline
\end{tabular}

Next, Chi-square analysis was performed on the frequencies of the five politeness strategies used by group 3 (female-high) and group 4 (female-low) participants in the L1. The results of this analysis are tabulated in Table13. Accordingly, the Chi-square values at 1 degree of freedom are 0.04, 0.60, 0.02, 0.56 , and 0.62 for strategies $1,2,3,4$, and 5 respectively. They are all smaller than the critical value of $\mathrm{x}^{2}(3.841)$ at the .05 level of probability. Therefore, the $\mathrm{x}^{2}$ values are not significant for the five strategies. This suggests that the relationship between female participants' SES and their use of the politeness strategies in L1 is not statistically significant. 
Table 13. One-way Chi-square: Inter-group relationship between female-high and female-low in terms of strategy use in L1

\begin{tabular}{|c|c|c|c|c|c|c|c|c|}
\hline \multirow[b]{2}{*}{$\begin{array}{l}\text { Strategy } \\
\text { L1 }\end{array}$} & \multicolumn{2}{|c|}{ Gender + Socio-economic Status } & \multirow[b]{2}{*}{$\begin{array}{l}\text { Expected } \\
\text { Frequency }\end{array}$} & \multirow[b]{2}{*}{$\begin{array}{l}\text { Total } \\
\text { (freq.) }\end{array}$} & \multirow[b]{2}{*}{$\begin{array}{c}\text { Chi Square } \\
\left(x^{2}\right)\end{array}$} & \multirow[b]{2}{*}{$\rho$-value } & \multirow[b]{2}{*}{$\operatorname{Phi}(\varphi)$} & \multirow[b]{2}{*}{$d f$} \\
\hline & $\begin{array}{c}\text { Female-High } \\
\text { (observed freq.) }\end{array}$ & $\begin{array}{c}\text { Female-Low } \\
\text { (observed freq.) }\end{array}$ & & & & & & \\
\hline 1 & 16 & 14 & 15 & 30 & 0.04 & 0.84 & ---- & 1 \\
\hline 2 & 182 & 198 & 190 & 380 & 0.60 & 0.43 & ---- & 1 \\
\hline 3 & 358 & 353 & 355.5 & 711 & 0.02 & 0.88 & ---- & 1 \\
\hline 4 & 12 & 17 & 14.5 & 29 & 0.56 & 0.45 & ---- & 1 \\
\hline 5 & 23 & 17 & 20 & 40 & 0.62 & 0.43 & ---- & 1 \\
\hline
\end{tabular}

\subsection{Analysis of socioeconomic status and politeness strategy use in speech act of request (L2)}

The participants' socioeconomic status and their use of politeness strategies in English were the other variables examined by means of Chi-square to see if there was a relationship between them. Table 14 displays the calculation results. It can be seen that the Chi-square values for strategies 1, 2, 3, 4, and 5 at 1 degree of freedom are in order $0.0,0.22,1.16,0.0$, and 0.68 , which are all smaller than the critical value of $x^{2}(3.841)$ at .05 level of probability.

Table 14. One-way Chi-square: The relationship between SES and politeness strategy use in L2

\begin{tabular}{ccccccccc}
\hline $\begin{array}{c}\text { Strategy } \\
\text { L2 }\end{array}$ & $\begin{array}{c}\text { Socio-economic Status } \\
\text { (observed freq.) }\end{array}$ & $\begin{array}{c}\text { High } \\
\text { (observed freq.) }\end{array}$ & Fxpected & $\begin{array}{c}\text { Total } \\
\text { Frequency }\end{array}$ & $\begin{array}{c}\text { Chi Square } \\
\left(x^{2}\right)\end{array}$ & $\rho$-value & Phi $(\varphi)$ & $d f$ \\
\hline 1 & 98 & 96 & 97 & 194 & 0 & 1 & ---- & 1 \\
\hline 2 & 221 & 232 & 226.5 & 453 & 0.22 & 0.63 & --- & 1 \\
\hline 3 & 425 & 458 & 441.5 & 883 & 1.16 & 0.28 & --- & 1 \\
\hline 4 & 14 & 15 & 14.5 & 29 & 0 & 1 & --- & 1 \\
\hline 5 & 30 & 23 & 26.5 & 53 & 0.68 & 0.40 & --- & 1 \\
\hline
\end{tabular}

In other words, the computed $\mathrm{x}^{2}$ values are insignificant for strategies $1,2,3,4$, and 5 . This indicates that, from a statistical point of view, there is not a significant relationship between the participants' socioeconomic status and their use of politeness strategies in English.

Ultimately, to investigate the relationship between the participants' SES and their use of politeness strategies in English with regard to their gender, Chi-square analysis was first applied to the frequencies of the five strategies used by group 1 (male-high) and group 2 (male-low) in their L2. Table 15 displays the results of this analysis. Accordingly, the calculated Chi-squares for the two variables at 1 degree of freedom are $0,0.02,0.42,0.56$, and 0 which are all smaller than the critical value of $x^{2}(3.841)$ at the .05 level of probability. Therefore, the $\mathrm{x}^{2}$ values are not significant for the five strategies which means that that there is not a statistically significant relationship between the male participants' socioeconomic status and their use of politeness strategies in English.

Table 15. One-way Chi-square: Intergroup relationship between male-high and male-low in terms of strategy use in $\mathrm{L} 2$

\begin{tabular}{|c|c|c|c|c|c|c|c|c|}
\hline \multirow[b]{2}{*}{$\begin{array}{l}\text { Strategy } \\
\text { L2 }\end{array}$} & \multicolumn{2}{|c|}{ Gender + Socio-economic Status } & \multirow[b]{2}{*}{$\begin{array}{l}\text { Expected } \\
\text { Frequency }\end{array}$} & \multirow[b]{2}{*}{$\begin{array}{l}\text { Total } \\
\text { (freq.) }\end{array}$} & \multirow[b]{2}{*}{$\begin{array}{c}\text { Chi Square } \\
\left(x^{2}\right)\end{array}$} & \multirow[b]{2}{*}{$\rho$-value } & \multirow[b]{2}{*}{$\operatorname{Phi}(\varphi)$} & \multirow[b]{2}{*}{$d f$} \\
\hline & $\begin{array}{c}\text { Male-High } \\
\text { (observed freq.) }\end{array}$ & $\begin{array}{c}\text { Male-Low } \\
\text { (observed freq.) }\end{array}$ & & & & & & \\
\hline 1 & 74 & 72 & 73 & 146 & 0 & 1 & ---- & 1 \\
\hline 2 & 71 & 74 & 72.5 & 145 & 0.02 & 0.88 & ---- & 1 \\
\hline 3 & 164 & 177 & 170.5 & 341 & 0.42 & 0.51 & $\begin{array}{ll}--- \\
---1\end{array}$ & 1 \\
\hline
\end{tabular}




\begin{tabular}{ccccccccc}
\hline 4 & 6 & 10 & 8 & 16 & 0.56 & 0.45 & $-\cdots$ & 1 \\
\hline 5 & 7 & 6 & 6.5 & 13 & 0 & 1 & --- & 1 \\
\hline
\end{tabular}

Meanwhile, as Table 16 exhibits, the results of the Chi-square analysis executed to the frequencies of the five super-strategies used by group 3 (female-high) and group 4 (female-low) participants English at 1 degree of freedom are $0,0.16,0.66,0.30$, and 0.62 in sequence. They are all smaller than the critical values of $\mathrm{x}^{2}(3.841)$ at the .05 level of probability. Thus, the $\mathrm{x}^{2}$ values are insignificant for strategies 1 , $2,3,4$, and 5 . With regard to these findings, it can be concluded that the relationship between the female participants' socioeconomic status and their use of politeness strategies in L2 is not statistically significant.

Table 16. One-way Chi-square: Intergroup relationship between female-high and female-low in terms of strategy use in L2

\begin{tabular}{|c|c|c|c|c|c|c|c|c|}
\hline \multirow[b]{2}{*}{$\begin{array}{l}\text { Strategy } \\
\text { L2 }\end{array}$} & \multicolumn{2}{|c|}{ Gender + Socio-economic Status } & \multirow[b]{2}{*}{$\begin{array}{l}\text { Expected } \\
\text { Frequency }\end{array}$} & \multirow[b]{2}{*}{$\begin{array}{l}\text { Total } \\
\text { (freq.) }\end{array}$} & \multirow[b]{2}{*}{$\begin{array}{c}\text { Chi Square } \\
\left(x^{2}\right)\end{array}$} & \multirow[b]{2}{*}{$\rho$-value } & \multirow[b]{2}{*}{$\operatorname{Phi}(\varphi)$} & \multirow[b]{2}{*}{$d f$} \\
\hline & $\begin{array}{c}\text { Female-High } \\
\text { (observed freq.) }\end{array}$ & $\begin{array}{c}\text { Female-Low } \\
\text { (observed freq.) }\end{array}$ & & & & & & \\
\hline 1 & 24 & 24 & 24 & 48 & 0 & 1 & ---- & 1 \\
\hline 2 & 150 & 158 & 154 & 308 & 0.16 & 0.68 & ---- & 1 \\
\hline 3 & 261 & 281 & 271 & 542 & 0.66 & 0.41 & ---- & 1 \\
\hline 4 & 8 & 5 & 6.5 & 13 & 0.30 & 0.58 & ---- & 1 \\
\hline 5 & 23 & 17 & 20 & 40 & 0.62 & 0.43 & ---- & 1 \\
\hline
\end{tabular}

\section{Discussion}

The first and the second research questions were about the relationship between the Iranian EFL students' gender and their use of politeness strategies while requesting in their L1 (Persian) and L2 (English). The results showed a statistically significant relationship between the participants' gender and their use of politeness strategies in both L1 and L2. A comparison of the frequencies of the strategies used by the two genders also revealed that male participants used strategy 1 (bald on record) much more than female participants, and that females used other strategies more than males did. In other words, male participants in this study tended to make their requests more baldly while females tended to use more indirect strategies. As an example, in situation (1) where the participants should ask their flat-mate to clean up the kitchen, this female student used off-record in her L1 and negative politeness strategy in her L2 while her male counterpart made his request baldly in both L1 and L2:

Sample responses for Situation 1 (L1 and L2):

$$
\text { مؤنث: آثشيزخونه دستتو مى بوس }
$$

L1 Female: [Ashpaz khooneh dasteto mibooseh] (Literally: "The kitchen kisses your hands")

$$
\text { مذكر : آثنبزخخونه رو تميزكن }
$$

L1 Male: [Ashpaz khooneh ro tamiz kon] (Literally: Clean up the kitchen)

L2 Female: Shouldn't you clean up the kitchen?

L2 Male: Clean up the kitchen.

The reason behind this difference could be related to the idea that most women, as Holmes (1995) suggests, use language as a means of keeping in touch, especially with intimates and friends. Another 
reason might be attributable to the fact that women's linguistic performance in many accounts is marked with hesitation and unassertiveness: Two factors which signify powerlessness; and this tendency leads to displaying negative politeness towards others (Mills, 2003). Women also use language to foster personal relationships. Their congeniality entails positive politeness, and since women's stereotypical behavior and niceness are interlocked, positive politeness is linked to women's linguistic politeness as well (Holmes, 1995). Briefly, females care about their interlocutors' feelings so much that sometimes they may even sacrifice their own will for not hurting their interlocutors because for a woman, above all, language is "an expression of concern for the feelings of others" (Holmes, 1995, p.4). On the other hand, men use language as a tool for obtaining and conveying information. This means that while men try only to convey their message as briefly as possible, women are worrying about not threatening the hearer's face.

The other reason for their difference, according to Brown and Levinson (1987), might be the higher relative power (R) that male speakers hold for themselves over the hearer and in turn the shorter social distance (D) that they perceive between the hearer and themselves. This makes males have less deferential behavior and as a result make more direct requests than their female counterparts do. On the other hand, females, holding lower relative power $(R)$ and perceiving longer social distance (D) between the hearer and themselves, have more deferential behavior, which make their requests more indirect.

The third and the fourth research questions were about the relationship between the Iranian EFL students' socioeconomic status and their use of politeness strategies while requesting in their L1 and L2. The results did not show any significant relationship between the participants' SES and their use of politeness strategies in L1 or L2. Socioeconomic status is a factor that according to many scholars determines social distance. Although Brown and Levinson (1978) believe that social distance makes high and low SES people employ different strategies, the results of the present study prove the opposite. The reason behind this finding might be grounded on the fact that social distance between the high and low SES groups is diminishing and the size of the middle-class is growing day by day. People from lower classes can quite easily have higher education and be in touch with the people from the high SES group. As it was the case with the participants of this study, more contact with educated people in the university context may have moderated the effect of SES and made the students feel shorter social distance and subsequently feel less deferent to others. Moreover, the availability and ease of access to various media may be another factor that has contributed to this sociolinguistic homogeneity. The more the social distance decreases, the less people of high and low SES feel a power gap among each other, and consequently the less they feel the need to reflect that difference in their speech. Having said that, had the participants been chosen from another social context or from a different age group, the results could have been different.

\section{Conclusions}

The results of the present study clearly show that females tend to use more politeness strategies than males; besides, males tend to use more direct strategies while females are inclined to use more indirect strategies in their requests. These findings are hoped to be a contribution to research on universals of language use. Although some scholars such as Lakoff (1973) have argued for the universality of politeness, some others (e.g. Brown \& Levinson, 1987; Haugh \& Bargiela-Chiappini, 2010; Kádár \& Haugh, 2013) are fully aware of the sociocultural dependency of politeness and accordingly claim that the abstract notion of 'face' (because of which politeness is exhibited) is universal, but that its exact content is subject to cultural specifications of many sorts. The results of this study which was conducted within the sociocultural context of Iran and on the Iranian speakers of Persian as a native language and 
English as a foreign language, clearly attests the validity of their claim. That said, it should be emphasized that to form a more comprehensive picture of the politeness universals and the variables that influence the choice of politeness strategies, further research should be conducted on miscellaneous age groups, ethnic communities, and regional dialects of Iran to see how these variables would affect the speaker's choice of politeness strategies while performing different speech acts.

\section{Ethics Committee Approval}

The author(s) confirm(s) that the study does not need ethics committee approval according to the research integrity rules in their country (Date of Confirmation: December 11, 2020).

\section{References}

Adler, N. E., Epel, E. S., Castellazzo, G., \& Ickovics, J. R. (2000). Relationship of subjective and objective social status with psychological and physiological functioning: Preliminary data in healthy, white women. Health Psychology, 19(6), 586-592.

Akbari, Z. (2002). The realization of politeness principles in Persian. Karen's Linguistics Issues, 12, $120-135$.

Bargiela-Chiappini, F., \& Harris, S. J. (1996). Requests and status in business correspondence. Journal of Pragmatics, 26(5), 635-662.

Brown, P., \& Levinson, S. C. (1978). Universals in language usage: Politeness phenomena. In E. Goody (Ed.), Questions and politeness: Strategies in social interaction, (pp. 56-310). Cambridge, England: Cambridge University Press.

Brown, P., \& Levinson, S. C. (1987). Politeness: Some universals in language use. Cambridge, England: Cambridge University Press.

Chen, S. C., \& Chen, S. H. E. (2007). Interlanguage requests: A cross-cultural study of English and Chinese. The Linguistics Journal, 2(2), 33-52.

Coates, J. (2015). Women, men and language: A sociolinguistic account of gender differences in language ( $3^{\text {rd }}$ ed.). London, England: Routledge.

Elmianvari, A., \& Kheirabadi, R. (2013). The study of EFL students' requests based on politeness theory. Journal of Language Teaching and Research, 4(2), 375-385.

Felix-Brasdefer, J. C. (2005). Indirectness and politeness in Mexican requests. In D. Eddington (Ed.), Cascadilla proceedings project. Selected proceedings of the $7^{\text {th }}$ Hispanic Linguistic Symposium (pp. 66-78). Cascadilla, MA.

Garcia, C. (1993). Making a request and responding to it: A case study of Peruvian Spanish. Journal of Pragmatics, 19(2), 127-152.

Goffman, E. (1967). Interaction ritual: Essays on face to face behavior. New York, NY: Pantheon Books.

Harlow, L. L. (1990). Do they mean what they say? Sociopragmatic competence and second language learners. The Modern Language Journal, 74(3), 328-351.

Haugh, M., \& Bargiela-Chiappini, F. (2010). Face in interaction. Journal of Pragmatics, 42(8), $2073-$ 2077. 
Holmes, J. (1995). Women, men and politeness. London, England: Longman.

Jalilifar, A. (2009). Request strategies: Cross-sectional study of Iranian EFL learners and Australian native speakers. English Language Teaching, 2(1), 46-61.

Kádár, D., \& Haugh, M. (2013). Understanding politeness. Cambridge, England: Cambridge University Press.

Kariithi, F. (2016). Politeness strategies used by youth in their language use. IOSR Journal of Humanities and Social Science, 21(7), 70-72.

Khandani, E. K. (2017). Requestive speech act realization patterns: Observations from Persian. Journal of Research in Applied Linguistics, 8, 104-124.

Lakoff, R. T. (1973). The logic of politeness: Or, minding your P's and Q's. Chicago Linguistics Society, 9, 292-305.

Leech, G. N. (1983). Principles of pragmatics. New York, NY: Longman.

Lorenzo-Dus, N., \& Bou-Franch, P. (2003). Gender and politeness: Spanish and British undergraduates' perception of appropriate requests. In J. Santaemilia (Ed.), Genero, lenguaje y traduccion, (pp. 187199). Valencia, Spain: Universitat de Valencia.

Macaulay, M. (2001). Tough talk: Indirectness and gender in requests for information. Journal of Pragmatics, 33(2), 293-316.

Marti, L. (2006). Indirectness and politeness in Turkish-German bilingual and Turkish monolingual requests. Journal of Pragmatics, 38(11), 1836-1869.

Mills, S. (2003). Gender and politeness. Cambridge, England: Cambridge University Press.

Niroomand, M. (2012). An exploration of upper-intermediate Iranian EFL learners' perception of politeness strategies and power relation in disagreement. English Language Teaching, 5(10), 180191.

Phillips, D. (2015). Longman preparation course for the TOEFL iBT test ( $3^{\text {rd }}$ ed.). White Plains, NY: Pearson Education.

Quraishi, S. (2009). The acquisition of politeness strategies by Afghan learners of English as a foreign language (Unpublished master's thesis). Retrieved from https://krex.kstate.edu/dspace/handle/2097/2347

Rafieyan, M. (2012). Evaluation of English language teaching departments of Turkish and Iranian universities in terms of politeness strategies with reference to request. International Journal of Applied Linguistics and English Literature, 1(5), 226-241.

Sahragard, R. (2003). A cultural script analysis of a politeness feature in Persian. Proceedings of the $8^{\text {th }}$ Pan-Pacific Association of Applied Linguistics, Japan, 399-423. Retrieved from http://www.paaljapan.org/resources/proceedings/2003/sahragard.pdf

Senowarsito, S. (2013). Politeness strategies in teacher-student interaction in an EFL classroom context. TEFLIN Journal, 24(1), 82-96.

Trosborg, A. (1995). Interlanguage pragmatics: Requests, complaints and apologies. Berlin, Germany: Mouton de Gruyer.

Yarmohammadi, N. (2003). Politeness strategies in English and Persian in contrast (Unpublished master's thesis). Allameh Tabatabai University, Tehran, Iran. 


\section{Cinsiyet ve sosyoekonomik durum: İranlı EFL öğrencileri tarafından Farsça ve İngilizce taleplerde kullanılan nezaket stratejilerinin pragmatik bir analizi}

\section{$\ddot{O} \mathbf{z}$}

Konuşmacıların bir konuşma eylemini gerçekleştirirken uyguladıkları nezaket stratejilerinin, aralarında cinsiyet ve sosyoekonomik durumun öne çıkan iki faktörden etkilendiği görülmüştür. Bu çalışma, bir yandan cinsiyet ve sosyoekonomik durum (SES) arasındaki ilişkiyi, diğer yandan da nezaket stratejilerinin seçimini incelemeye yönelik bir girişimdi. Odak noktası, özellikle Farsça (L1) ve İngilizce (L2) dillerinde talep edilen konuşma eyleminin gerçekleştirilmesiydi. Katılımcılar 100 ileri düzey İranlı EFL öğrencisiydi. Cinsiyetlerine ve sosyoekonomik durum anketine verdikleri yanıtlara göre, yirmi beşlik dört eşit gruba ayrıldılar: 1. erkek-yüksek; 2. düşük erkek; 3. kadın yüksek; ve 4. düşük kadın. Veri toplama araçları, bir söylem tamamlama testinin (DCT) İngilizce ve Farsça versiyonlarıydı. Sonuçlar, L1 ve L2'de istek üzerine konuşma eyleminde cinsiyet ile nezaket stratejilerinin kullanımı arasında anlamlı bir ilişki olduğunu ortaya koydu. Bununla birlikte bulgular, katılımcıların sosyoekonomik statüsü ile nezaket stratejisi kullanımları arasında ne L1 ne de L2'de anlamlı bir ilişsi olmadığını göstermiştir. Bu çalışma, Brown ve Levinson'un nezaket stratejilerinin evrenselliği konusundaki iddiasının bir başka kanıtı olabilir.

Anahtar Sözcükler: nezaket stratejileri; Cinsiyet; sosyo-ekonomik durum; konuşma talebi

\section{AUTHOR BIODATA}

Farzaneh Khakzad Esfahlan earned her B.A. in French language translation and her M.A. in TEFL both from Allame Tabatabai University, Tehran, Iran. In 2012, she moved to Turkey and started working as an English language teacher at Istek K12 School in Istanbul. Later she joined İhlas K12 School, and more recently, in 2018, she became an instructor in the English preparatory program of Istanbul Şehir University. She has taught a wide range of courses to students from different age groups and at various levels of English proficiency. Her major research interests include sociolinguistics, pragmatics (with a focus on politeness), ethnolinguistics, second language acquisition, and learning strategies.

Mohsen Boroumand obtained his B.A. in English language from Shahid Chamran University (Ahvaz, Iran) and his M.A. in TEFL from Allame Tabatabai University (Tehran, Iran). At present, he resides in Istanbul, Turkey, and works as an English language instructor in the English preparatory program of Istanbul Aydin University. Before joining Aydin Universiy, he worked at Istanbul Şehir University (2017-2020), Özyeğin University (Istanbul, 2013-2015), and Islamic Azad University (Dezful branch, Iran, 2008-2012). He has taught miscellaneous English courses to undergraduate and preparatory program students including EAP, grammar, advanced writing, literature, and linguistics. His research interests include sociolinguistics, pragmatics, ethnolinguistics, second language acquisition, and learning strategies. 